\title{
The Comparison and Experiential Learning in the Metropolitan Delta
}

\author{
Yan Wang ${ }^{1,2,}$, Wei $\mathrm{Wu}^{3}$, Luuk Boelens ${ }^{2}$ \\ ${ }^{1}$ School of Architecture, Southeast University, Nanjing, China \\ ${ }^{2}$ Centre for Mobility and Spatial Planning, Ghent University, Ghent, Belgium \\ ${ }^{3}$ Jiangsu Institute of Urban Planning and Design, Nanjing, China

\section{Email address:} \\ yan.linda.wang@hotmail.com (Yan Wang),3635382@qq.com (Wei Wu), Luuk.Boelens@UGent.be (Luuk Boelens) \\ ${ }^{*}$ Corresponding author
}

\section{To cite this article:}

Yan Wang, Wei Wu, Luuk Boelens. The Comparison and Experiential Learning in the Metropolitan Delta. Urban and Regional Planning. Vol. 3, No. 2, 2018, pp. 64-72. doi: 10.11648/j.urp.20180302.14

Received: July 31, 2018; Accepted: August 30, 2018; Published: September 18, 2018

\begin{abstract}
Throughout the history of the world, the development of cities is inseparable from the large water system and the ocean. The world-class urban agglomerations are concentrated on the delta metropolitans that water-affluent areas. Since ancient times, the whole world has commonness in delta`s development. Since the 1980s, the massive urbanization processes featuring the typical Time-Space compression, enhance complicated conflicts in China's daily life. The enormous floods of the global climate change, soil erosion, environmental pollution, water resources waste, and the loss of hydrology landscape also affect the urban development. As a result the Chinese government has induced the "New urbanization", "Sponge City- project" and so forth, "Scientific urbanization" and sustainable ecological urban planning gain wide attention. This paper will focus on the urban development of the Delta metropolitans. The methods of literature research, re-mapping, case sudy, comparative study, multi-perspective study will be applied in this paper. It will take the Yangtze River Delta and Euro Delta as examples, compare the similarities and differences of these two deltas in perspective of urban morphology and delta governance. The aspects of urban morphology contains city site selection, urban form and urban elements, the cores evolution and historical superposition of urban agglomeration. Actor, factor, institution, as the city gene leave their traces on the urban fabric. The paper also learns the experiences of water management and city-group development from both deltas. The Yangtze River Delta could learn from the Euro Delta in terms of the urban revitalization and the reconstruction of waterfront areas. In conclusion, it will give suggestions for future's urban resilience development.
\end{abstract}

Keywords: Metropolitan Delta, Comparison, Experiential Learning, Urban Resilience

\section{Introduction}

Throughout the history of the world, the development of cities is inseparable from the large water system and the ocean. The world-class urban agglomerations are concentrated on the delta metropolitans that water-affluent areas. Delta metropolitan has a high population density because of the fertile land and the well-developed agriculture in history. These areas have bloomed into concentration of industry due to the convenient transport. Since ancient times, the whole world has commonness in delta's development.

Since the 1980s, the massive urbanization processes featuring the typical Time-Space compression of David
Harvey (1989), enhance complicated conflicts in China`s daily life. The historical cities have undergone tremendous changes, where the historical spaces go through fragmented processes by the new buildings construction and the transformation of traditional streets. The enormous floods of the global climate change, soil erosion, environmental pollution, water resources waste, and the loss of hydrology landscape also affect the urban development [1]. As a result, "Sustainable Development", "Ecological City", "Low-carbon City", "Green urbanism", "Low Impact Development”(Green Roof in German, "Best Management practices" in USA, "Sustainable Urban Discharge system" in UK), "Water Sensitive Urban Design" in Australia, "Resilient City", such 
ideas and concepts of the environmentalist paradigm are issued in recent years. Chinese government has induced the "New urbanization", "Sponge City project" and so forth, "Scientific urbanization" and sustainable ecological urban planning gain wide attention.

These years, Chinese government pays high attentions on metropolitan delta's development, like "City Cluster Plan for Yangtze River Delta" (May, 2016), the Guangdong-Hong Kong-Macao Greater Bay Area is approaching new strategy and ideas in new era. In 2016, Copenhagen launched the Blue-Green Strategy "The Copenhagen Cloudburst Formula". This year, the institution in England puts forward a vision of "Walkable London". Both Europe and China are pursuing more resilient ways to promote the sustainable development of cities.

This paper will focus on the urban development of the metropolitan deltas. The methods of literature research, re-mapping, case sudy, comparative study, multi-perspective study will be applied in this paper, concentrating on the comparison of metropolitan delta from urban development and delta governance perspectives, learning from each other with experiences in urban development and water management for future challenges, in order to restore the resilience of the cities and strengthen urban adaptability and sustainability.

It will take the Yangtze River Delta and Euro Delta as examples, compare the similarities and differences of these two deltas in perspective of urban morphology and delta governance. The aspects of urban morphology contains city site selection, urban form and urban elements, the cores evolution and historical superposition of urban agglomeration. Actor, factor, institution, as the city gene leave their traces on the urban fabric. The paper also learns the experiences of water management and city-group development from both deltas. The Yangtze River Delta could learn from the Euro Delta in terms of the urban revitalization and the reconstruction of waterfront areas. In conclusion, it will give suggestions for future's urban resilience development.

\section{Comparison Between Two Deltas-Similarities and Differences}

The Yangtze River Delta is one of the highest population density and immigrant areas in China, with numerous big cities that contribute to making it China's largest economic zone. It covers an area of 99,600 square kilometres $(38,500$ sq mi) and is home to over 115 million people [2]. From the definition of the delta, the real Yangtze River Delta is situated south of Jiangsu Province and present-day Shanghai. The urban history of this delta is not only characterized by human defence against regular flooding and/or changing river mouths, it is a region whose urban settlements have prospered from ancient time to present day, in regard to water-city interaction, seven spatio-cultural stage characteristics came through the periods of Early Physical
Geography and Settlement Development $(<4000$ BC), the Formation of the City $(<-200 \mathrm{BC})$, the First Canal Urban System (250 BC-600 AD), Grand Canal Urban System (550 AD-950 AD), Water Cities (900 AD-1400 AD), Diversification of Urban Development (1350 AD-1850 AD), The Rise of Railways and the Urban National Industry (1800 AD-1950 AD) [3]; and witnessed the prosperous of cities of Nanjing, Yangzhou, Suzhou and Shanghai, etc.

The Euro Delta is commonly defined as the area of and between the Dutch Randstad, the Flemish Diamond and the Rhine-Ruhr, consisting of numerous mid-sized cities with a maximum population of one million, but more commonly with between two hundred thousand or some tens of thousands inhabitants. However, and depending on how the area is defined, the total the Euro Delta population could amount to 33.5 million, scattered around an area of some 52,000 square kilometres, and contributing to some 15-60 percent of the GDP of the respective countries of Germany, the Netherlands or Belgium, including about twenty-five headquarters of the Fortune Global 500 corporations [4]. (Figure 1).

The region that the Rhine, the Meuse, the Scheldt flowing through experiences the early settlement period, Dorestad in 8th -12th AD, The time of Bruges in 12th -14th AD, The time of Antwerp in 14th $\mathrm{AD}$, The time of Amsterdam in 16th -18th $\mathrm{AD}$, the Coalbasins/Ruhrarea in 18th $\mathrm{AD}$, by the 20th and 21st centuries, the Euro Deltas forms. To the balanced development of medium-sized cities, the multi-centres are constituted by the capital city Brussels, industrial city Ghent, international port city Antwerp, Rotterdam, tourist city Bruges, etc.

Based on the research of the theoretical framework in the interaction of "water and city", from time and space, urban form includes water environment and city site slection, water and urban regional environment, water and the evolution of urban space, water and the urban spacial elements (transport, defense, life style......), which establish their own system and interplay with each other. On the aspect of urban governance, influencing factors, actors and institutions constitute the dynamic mechanism, where they act on and interact with each other. The cities' development is related to a complex co-evolution of urban form and urban governance [5].

It seems that "bottom-up, water-adaptive and polder urbanised" [6] Euro Delta be different from the "top-down, water infrastructure and authority-driven urbanisation" of the Yangtze Delta. Nevertheless, after compared these two deltas from urban morphology and urban governance, we also find there are similarities. The paper will compare the Yangtze River Delta and the Euro Delta in the perspective of urban morphology from "city site selection, urban form and urban elements, the cores evolution and historical superposition of urban agglomeration". And the similarities and differences in urban governance are highlighted in the aspects of factors, actors and institutions, as shown in Table 1. 


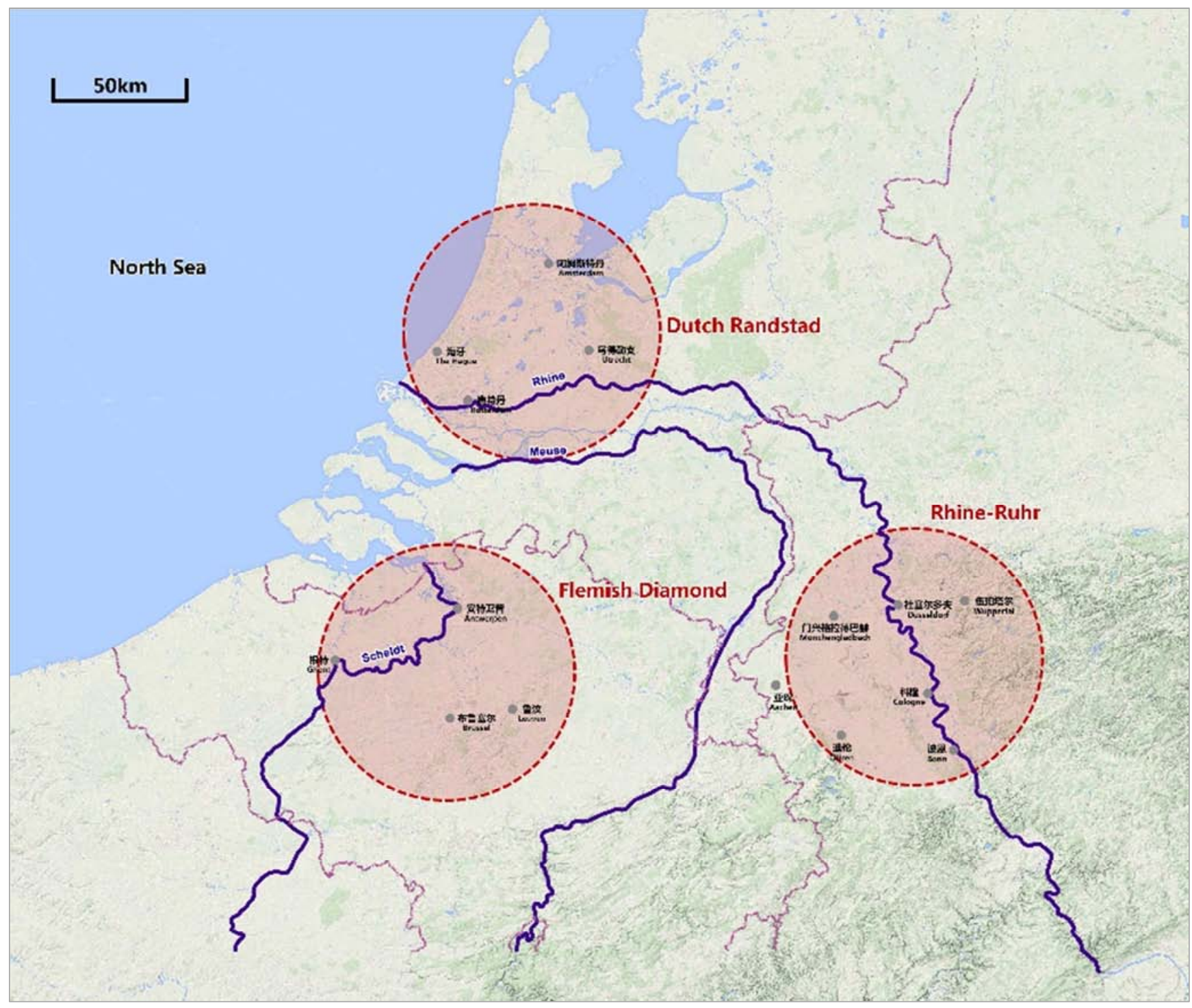

Figure 1. The Euro Delta.

Table 1. The comparison of the interaction of water and city between the Yangtze River Delta and the Euro Delta.

\begin{tabular}{|c|c|c|c|}
\hline \multicolumn{3}{|c|}{ Comparative analysis } & \multirow{2}{*}{$\begin{array}{l}\text { Similarities and Differences } \\
\text { Similarity: security, effectiveness, sustainability }\end{array}$} \\
\hline \multirow{4}{*}{$\begin{array}{l}\text { urban } \\
\text { morphology }\end{array}$} & Settlement level & Urban location feature & \\
\hline & City level & $\begin{array}{l}\text { Urban forms and urban } \\
\text { elements }\end{array}$ & $\begin{array}{l}\text { Generally different; } \\
\text { Developed from the economic centre, the urban form is similar, free and organic; } \\
\text { Military functions of the city, are made up of walls, gates, trenches. }\end{array}$ \\
\hline & \multirow[b]{2}{*}{ Regional level } & $\begin{array}{l}\text { Core Evolution of Urban } \\
\text { agglomeration }\end{array}$ & $\begin{array}{l}\text { Similarity: the core of urban agglomeration increases alternately under the influence of } \\
\text { various elements of urban governance (factors, actors, institutions). }\end{array}$ \\
\hline & & Historical superposition & $\begin{array}{l}\text { Similarity: The location of the huge city groups is the concentration area of the ancient } \\
\text { settlements and the city relics. The ancient relics and the modern cities' archipelagos } \\
\text { present a remarkable additivity. }\end{array}$ \\
\hline \multirow{5}{*}{$\begin{array}{l}\text { Urban } \\
\text { governance }\end{array}$} & \multirow[t]{2}{*}{ Factor } & Urban origin & Generally different \\
\hline & & Common features & $\begin{array}{l}\text { The basic factors are all natural factors; the fundamental factors are traffic factors; the } \\
\text { direct factors are military politics, and the potential factors are cultural factors. }\end{array}$ \\
\hline & & $\begin{array}{l}\text { Water management } \\
\text { technology innovation }\end{array}$ & $\begin{array}{l}\text { Urbanization in the two deltas has also been driven by technological innovations in } \\
\text { sustainable and resilient water management }\end{array}$ \\
\hline & Actor & Actor & Generally Different, merchants, guild status is different. \\
\hline & Institution & $\begin{array}{l}\text { Management system } \\
\text { Culture }\end{array}$ & $\begin{array}{l}\text { Generally Different, The economic function enters the city role, bottom-up appears; the } \\
\text { political function enters the city role, top-down appears. }\end{array}$ \\
\hline
\end{tabular}




\section{Learning About Future Challenges}

Both China and Europe are the important origins of human civilization. Since the middle ages, the cities have developed rapidly in Europe. From the industrial revolution in eighteenth Century, it promoted the process of industrialization and urbanization in Europe. China, which also has a long and glorious history of urban development, is pushing forward the process of maximum urbanization in human history. In an important speech delivered in 2014 at the European Institute in Bruges, Belgium, Chinese President Xi Jinping pointed out: "both China and the European Union are undergoing an unprecedented reform process in the history of human beings. Both sides should strengthen dialogue and cooperation in the fields of macroeconomic, public policy, regional development, rural development, and people's livelihood, respect the reform path, learn from the reform experiences with each other, and promote the development and progress of the world with their own reforms. "From 28 March to 2 April 2017, the "China-EU Cooperation on Sustainable urbanization" project, "China-EU Innovation platform for Sustainable urbanization", jointly funded by the General Bureau of Scientific Research and Innovation of the European Union and the Ministry of Science and Technology of China, held a project launch meeting and a seminar on the implementation programme. Kostas Glinosi, Director of the International Cooperation Division of the European Commission's General Directorate of Scientific Research and Innovation, said at the launch meeting: "The EU attaches great importance to the China-EU sustainable urbanization innovation platform project, which will provide a strategic report on the policies of EU and China in the sustainable development of urbanization, and has important reference value. At the same time, We hope to create new development opportunities by building collaborative and innovative platforms, strengthening links with markets and enterprises, breaking down barriers in government, academia and business communities, and working together to address the enormous challenges posed by current urbanization. [7]" In order to jointly address the problems and challenges that arise in the development of urbanization, what useful development experiences could we learn in the process of urbanization and the management of water systems, making our cities more adaptable and sustainable will be the focus of this paper.

\subsection{Development Experience of the Yangtze River Delta}

The interactive development of water and city in the Yangtze River Delta metropolitan area has experienced the agricultural times, and the industrialization era, at present, it is experiencing the post industrialization era. The paper learns the experiences of water management and city-group development from both deltas, it could be concluded that the experiences of water management in the Yangtze River Delta include paying attention to the location of the city, choosing the suitable living environment, unified governance, systematic diversion, rational utilization and so on. The development experience of urban agglomeration mainly contains overall strategic planning, "high-speed rail urban network" model, "industry-city" cooperative governance mechanism and so forth.

\subsubsection{Water Management Experience}

The historic water management measures in the Yangtze River Delta have been introduced in detail at the regional and urban levels, and the wisdom of the ancients is also reflected in the interaction between the city and the water. Most of the cities in ancient China go through careful city location, and the ancient urban planning thought of China also has a unique view on urban location. Chinese geomantic theory is ancient geography, meteorology, landscape science, ecology, the comprehensive system of urban architecture, which reflects the relationship between landscape and its context[8]. The water source, the relationship between the city and the water are the factors that must be considered in the city siting. Nanjing city is located southeast China the coast, at the Yangtze River downstream, surrounding terrain is of great strategic importance, and the Gong city is located in the north of the centre of the capital, and around the city, a series of castles and military sites are built in accordance with the terrain, building a complete defense system. Suzhou is a city that "understands soil quality and water conditions, looks at celestial phenomena and geomantic waters". Most cities in the Yangtze River Delta are linked to rivers, seas, and lakes, and take natural mountains and rivers as an important reference condition for siting. Full consideration is also given to the link between water transport and the city. For example, the changes of Yangzhou city sites in different periods, the changes of the Yangtze River estuary coastline, which have the influence on the Zhenjiang city site scope. Such as the connection between Suzhou city and Shanghai and the sea, etc. It is at the very beginning of the city construction that the city location and water sources are fully considered. Through the analysis of the morphological changes of Yangtze River Delta, the general law of urban development in ancient China, namely, stability and superposition, could be reflected.

The construction of the Grand Canal is one of the important conditions for the prosperity and development of the Yangtze River Delta. It is the embodiment of integrated strategic deployment and planning of water system management engineering in ancient times. It constitutes an integrated transport network, an integrated economic network, a living network, and a pattern of urbanization network closely linked by water system. From the central to the local level, water management is one of the important duties of local officials. In the period of more mature urban development, the water management responsibilities are more subdivided, with special water management departments. And there are related works on water management. In the water conservancy records of the regions or cities, the detailed measures taken by the different dynasties to control the water are also recorded in detail. It is from the central to the local unified governance and system guidance, so that it could make better use of water resources 
to promote urban development.

The water and land city gates, and the water gates are opened regularly according to the need. The ancient city has its own system of river channels, "the water and land are parallel, and the river and street are adjacent". It presents water and land double chessboard pattern, and links the Grand Canal outside the city to water transport, facilitating the exchange of goods and materials. It makes rational use of the water system and water transport system in the city, and promotes the ecological recycling. The ancient city of Suzhou is completely preserved, and the pattern of the water system determines the urban pattern, it is the reason that the pattern of Suzhou city not be changed for more than 2000 years. Based on the water system, the construction of bridges, the development of gardens and the construction of city gates reflect the historical extensibility of ancient Chinese cities. The gardens in Suzhou, the "ten sights of the West Lake" in Hangzhou, the mountains and rivers of Zhenjiang, Chinese ancestors also create the wisdom and culture of the East in their interaction with water. There are many lines in ancient Chinese poetry describing urban landscapes, "Gusu prosperous picture" shows the bustling life of the riverbank. Melting in the landscape, natural landscape combined with local regional culture, creates a unique landscape with Chinese characteristics of the landscape city.

\subsubsection{Urban Agglomeration Development Experience}

\section{(i) Overall Strategy and Planning}

The Grand Canal represents the overall water infrastructure strategy and planning in ancient China and promotes a large number of cities' prosperous. In contemporary era, "City Cluster Plan for Yangtze River Delta" fosters a higher level of economic growth pole [9]. "Urban system Planning in Southern Jiangsu Province (2012-2030)" proposes two circles and three zones of development structure to build Nanjing Metropolitan Circle, Suxichang (Suzhou, Wuxi and Changzhou) Metropolitan Circle, Ninghang (Nangjing and Hangzhou) Industrial Belt, Huning (Shanghai and Nanjing) Industrial Belt and Industrial Belt along the Yangtze River, in order to guide the transformation and upgrading of Southern Jiangsu. It is of great significance to promote the establishment of a national innovation demonstration area and the modernization, and to lead and support the construction of the core area of world class urban agglomeration in Southern Jiangsu [10]. In 2013, with the approval of the State Council, the National Development and Reform Commission recently officially issued the "demonstration Zone Plan for the Modernization of Southern Jiangsu Province", marking the first regional plan with the theme of modernization in China to be promulgated and implemented. In the planning, the functional orientation of the major cities such as Nanjing, Wuxi, Changzhou, Suzhou and Zhenjiang is specified, which is conducive to the innovation of the economic and social development model in Southern Jiangsu and the further improvement of the quality of economic and social development. It speeds up the construction of regional modernization at a higher level and promotes coordinated regional development across the country [11].

\section{(ii) "High-Speed Train + Urban Network" Mode}

Sixty percent of the world's high-speed trains are in China. By the end of 2016, China had 22,000 kilometres of high-speed trains. By 2020, China's rail network is expected to reach 150,000 kilometres and high-speed trains will reach 30,000 kilometres [12]. By 2025, it will reach 38,000 kilometers. All cities with a population of 500,000 will be connected [13]. According to the "Medium and Long Term Railway Development Plan of China", in order to meet the increasing demand for passenger transport by 2020, a rapid passenger transport corridor between provincial capitals and large and medium-sized cities will be established. The national railway network will form two hours, four hours, eight hours and other different levels of transport to promote economic development in the region [14].

The high-speed rail network and the connected urban agglomerations and the vast hinterland shorten the time and space between the cities. The cities linked by high-speed rail network in the Yangtze River Delta have entered the 2.5 hour traffic circle. Shanghai, the capital city Nanjing and Hangzhou have entered the 1 hour traffic circle. The high-speed rail network strengthens the urban links between the north and south wings of the Yangtze River Delta and promotes the flow of factors of production such as people flow, material flow, capital flow and information flow, and the coordinated development among cities. The node advantage of important cities is reduced, the whole long delta region begins to change from single or several centres to multi-function centres, and the cities also develop with each other. Under the impetus of Shanghai, Nanjing Metropolitan Circle, Hangzhou Metropolitan Circle, Hefei Metropolitan Circle, Suxichang (Suzhou-Wuxi-Changzhou) Metropolitan Circle and Ningbo Metropolitan Circle began to develop as in the same city. Now, Shanghai Metro Line 11 has been extended to Huaqiao Station in Kunshan, Jiangsu Province, becoming the first inter-provincial subway in China. Relying on the integration of transport, more and more people living in Shanghai are willing to work in Kunshan, making it possible to commute to other places. A day's round trip is possible.

High-speed railway blurs the boundary of urban agglomeration, and the construction of metropolitan area breaks through the restriction of administrative regionalization. It reaches another city group in two hours along the important high-speed railway line, and many urban agglomerations form the network of cities on a national scale. This kind of urban network is not only the network on the main lines of transport, but also the integration of urban production and lifestyle. "High-speed rail+manufacturing", "high-speed rail+logistics", "high-speed rail+service", and so on, the coordination of traffic construction and industrial development has become a new trend of regional spatial development in the Yangtze River Delta, and the Internet will further strengthen such urban networks. This urban network 
is reflected in all aspects of the media, retail, culture, tourism, finance, education, industry, etc. The coordinated development trend of "industry and city" in the Yangtze River Delta region is remarkable. The progress of traffic mode is the technical guarantee, and the rise of "Internet + " is the motive mechanism for the formation of new urban network [15]. The Yangtze River Delta region has formed a mega-urban area with high efficiency and urban network (Internet, transport network, production network, life network). The Yangtze River Delta is the most dynamic urban agglomeration in China, it has already formed the "high-speed rail +urban network" model.

\subsection{Development Experience of the Euro Delta}

\subsubsection{Urban Agglomeration Development Experience: Multi Centre, Balanced City, Network City}

Since the establishment of the European Union, especially in recent years, more and more attention had been paid to urban policy. In the 1990 s, the European Union proposed to strengthen the urban community policy within the framework of EU policy. In the policy document of 2000, the importance of regional level in policy formulation was first tried to promote the sustainable development of cities. In 1990, the "Green Paper on Urban Environment" explored a more intensive and mixed development model. In 2007, the "Leipzig Charter" addressed the issue of sustainable European cities and recommended that countries seriously consider the spatial impact of urban development processes. The European Space Development Strategy in 1999 created the concept of "balanced city", and the balanced regional development was realized by the multi-center city system. There were also strategic transnational policy documents, such as the 2007 "Territorial Agenda", the "territorial integration" of the "2009 EU Operational Treaty". The "EU 2020 Strategy", launched in 2010, called for "smart growth, sustainable growth and inclusive growth" and a resilient and inclusive economic environment. In addition, the European Union's efforts at the city level were also taking shape, such as the "integrated urban development" approach to the "Urban Act" project, which used excellent practice cases to draw lessons and stimulate the spirit of urban innovation. From 2000 to 2006, "strengthening economic clusters, increasing the attractiveness of central cities, reducing poverty and social spatial segregation, reusing large old industrial bases and improving local transport conditions", etc., were reflected at the spatial level. Between 2007 and 2013, progress was made in "promoting the integration of poor neighbourhoods, sustainable urban development, a more balanced, multi-centric development model and developing urban networks". The "Land agenda 2020" emphasized the principle of multi-centre development and land priority development, and improved urban transportation accessibility, so as to improve job opportunities and public services [16].

The Euro Delta (the Dutch Randstad, the Flemish Diamond, the Rhine-Ruhr) is well positioned to implement the multi-centre strategy proposed by the EU. In this region, there is no polar core model of an international metropolis, but a metropolitan area composed of medium and small cities with high population density and the world's largest seaport. It is polycentric, the cities have their own characteristics, and the urban development presents an orderly network feature. The cities in the Dutch Randstadad and Flemish Diamond region are independent of each other, similar in size and with a clear division of specialization. For instance, Brussels is the headquarters of the European Union, Antwerp is a famous port city and fashion capital. Amsterdam in the Randstadad region is the capital of the Netherlands and the economic and cultural centre. The Hague is the political centre, Utrecht is an important waterway hub, while Rotterdam is the largest port. In its physical space planning, the Netherlands proposes to strengthen the construction of a network city. In "The Fifth Memorandum on Physical Planning", it proposed "transforming (public) traffic nodes into new city centres; improving internal and external accessibility; developing a balanced and sustainable environment, realizing all the space requirements of the region itself ", and puts forward the concept of" Deltametropool "[17]. The Dutch Randstad relies on convenient transport, abundant university resources and scientific research institutions, as well as a superior ecological environment, gradually forms a complex regional innovation network.

The Rhine-Ruhr of Germany presents a multi-point distributed network model. This region includes the large German cities of Essen, Dusseldorf, Cologne, Dortmund and Duisburg. The population in every city is more than 500,000 , and there are many, balanced and small cities around them. The urban development of this region is characterized by balanced development, and no city is dominant, although the cities of Essen, Dusseldorf, Cologne, Dortmund and Duisburg are large and at the heart of the region. However, it is still in parallel competition and development position with many other political independence and smaller cities [18]. Each big city has its own dominant industries, which are related to and complement each other, but develop differently.

Through a series of initiatives such as political alliances, economic alliances, urban policy guidelines and so on, the European Union aims to facilitate the flow of money, talent, information, labour among member states, so that the regional resources are further optimized. The "delta metropolis" network city with multi-centre and balanced urban development is gradually formed in the Euro Delta.

\subsubsection{Urban Renewal: History as a Resource for Urban Growth}

European cities have a strong historical background, modern life and urban activities in the historical buildings do not appear very abrupt. What contributes to this fusion, and what facilitates the dialogue between history and the present in the present time and space? Through the detailed analysis of many historical cities, it is found that these cities all have obvious commonalities. Instead of isolating history, historical resources could continue to realize their own value in contemporary development, and to promote urban 
development better. In the Euro Delta, Bruges as a world cultural heritage city, water environment as a historical context is an important link in the historical landscape, which is a continuous landscape and historical memory. The iconic medieval historical buildings, the existence of the point historical memory and the linear historical context of the series of water systems, and the rich urban activities and city languages, form a continuous, running historical landscape pattern. History is a good interpretation of the past and the future. The ancient city of Ghent, an industrial city, developes separately from the port of Ghent and promotes each other without interference. Antwerp, with its important strategic position on the Scheldt River, has since ancient times promoted the development of the city in accordance with the port. Port area construction has become the city's best business card.

\subsubsection{Reconstruction and Renewal of Waterfront Areas: Culture Leads to Urban Vitality}

Antwerp Het Eilandje becomes a model for the industrial waterfront revival. The Het Eilandje area is the earliest artificial dock area in Antwerp. It is the intersection of the old city and the new port area. The main mode of revival is the transformation of historical buildings into cultural buildings (museums, etc.), supplemented by living, commercial, office, etc., traditional and modern blending, it becomes the "historical and cultural axis" of historical city and the new port area. Through the renovation and utilization of historical buildings, a museum (MAS) which could overlook the whole city of Antwerp has been added to complete the transformation from the old working dock to the museum dock. The buildings of residential, commercial, office, school and so on have been completed, making the Het Eilandje a vibrant cultural living area [19]. (Figure 2, Figure 3)

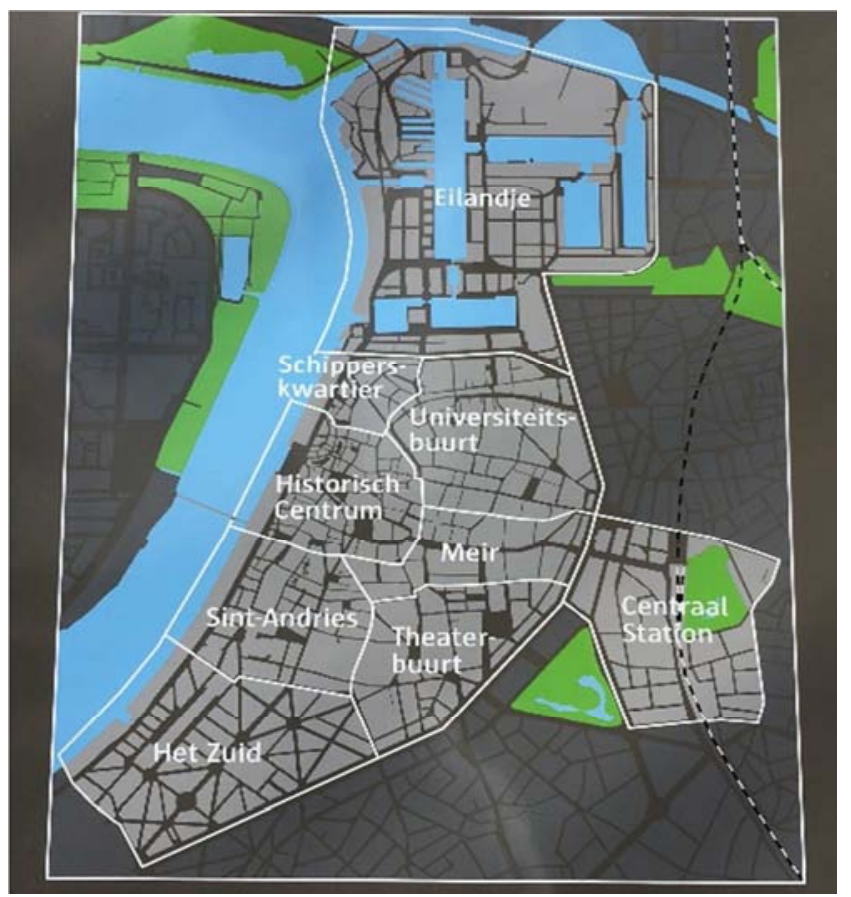

Figure 2. Map of the centre of Antwerp.

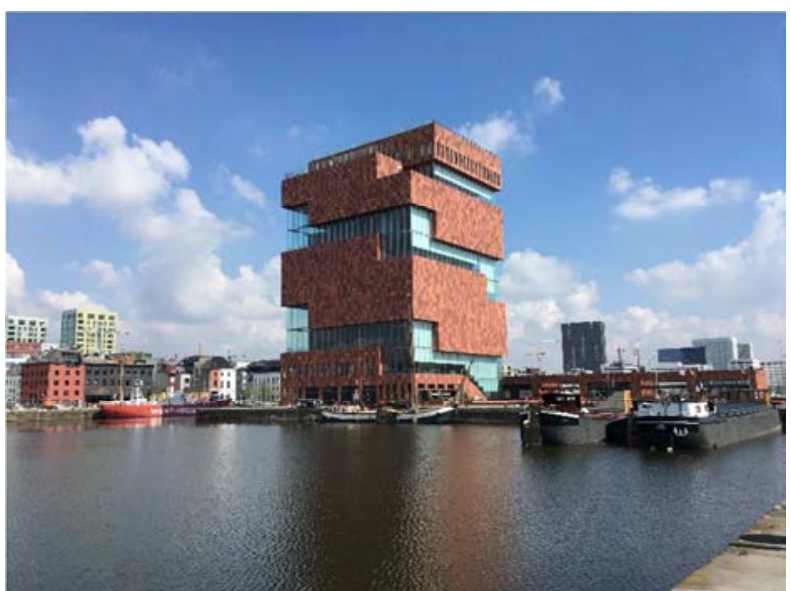

Figure 3. MAS, Het Eilandje.

In the first century $\mathrm{BC}$, the Romans built Londinium, the location of present-day London, on the north bank of the Thames [20]. The prosperity of the industrial revolution had a great impact on the environment of the Thames. In the middle of the 20th century, the British government had decided to rehabilitate the Thames. From the 1960s to the 1970 s, a series of water management laws and regulations were formulated. The establishment of water management mechanism, water operation organization and so on, calling on the public to participate in environmental protection and other technical means, had greatly improved the ecological environment of Thames River.

London's space strategy defines the banks of the Thames as a central area of activity and aims to build a globally influential financial and business centre. First, it is to protect and redevelop the important historical elements such as Parliament Building, London Bridge and St. Paul's Cathedral, and pay attention to the preservation of the industrial cultural heritage, preserve the regional context, forming a special space zoning. The second step of revival is to inject cultural elements to active the new vitality of this area. Cultural buildings, such as bookstores, museums, art gallery transformed from factories and so on, are developed on the basis of cultural facilities such as cinemas and theatres. At the same time, business and finance functions are added into this region.

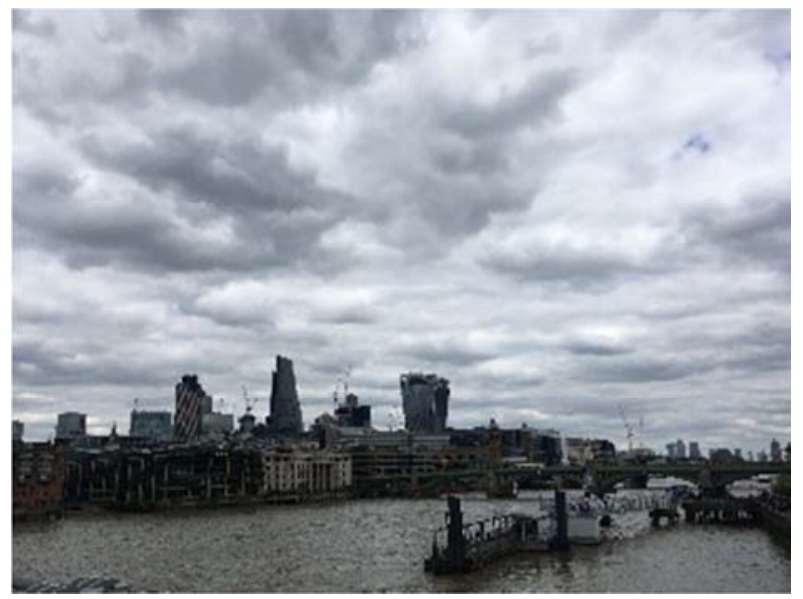

Figure 4. Thames waterfront area. 


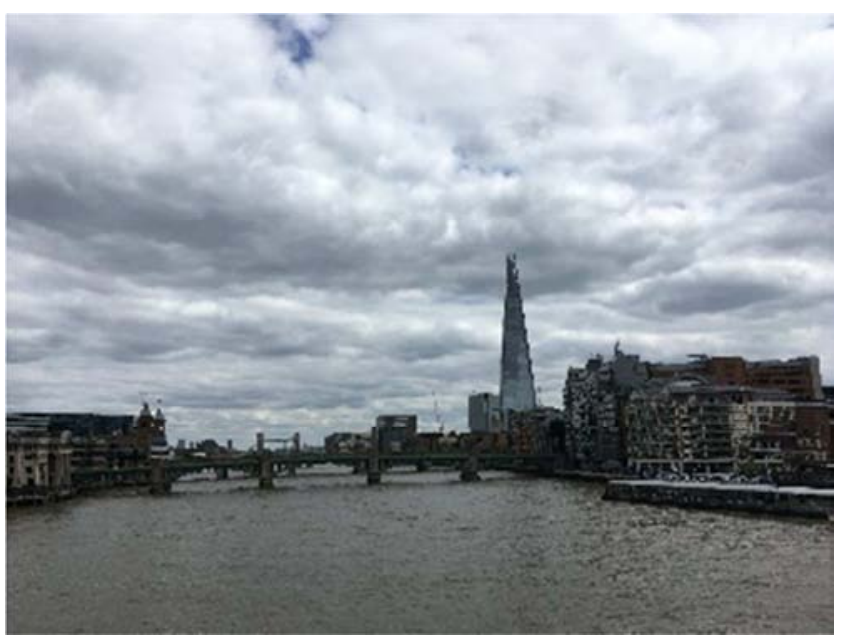

Figure 5. Thames waterfront area.

The waterfront walkway along the coast takes the "flowing history" as the cultural context, and series up various functions and stages to form a "vivid" and "operated" waterfront recreation system. The reconstruction and rejuvenation of waterfront areas, it is to inject cultural elements to enhance the vitality of the region. With the development of urban space, historical buildings, landmarks and so on, the city landscape on both sides of the Thames River has become London's vivid city card. (Figure 4, Figure 5)

\subsubsection{Water Management Experiences: "Landscape+Engineering", Combination of Design and Water Management}

One of the characteristics of Euro Delta cities in history is that their prosperity inseparable from the sea. The Netherlands, a country as a whole belows sea level, has extensive experience in water management. In the process of reconstructing nature by nature, it explores "landscape+engineering" and "Dutch model" that designs combined with water management.

The Dike local system in Holland is closely linked to its urban system and landscape functions. Since fifteen century, windmills have become effective drainage assistants. The windmills drain the low-lying water into the canals and sea through a series of dyke systems. The Kinderdijk windmill groups in southern Holland province were built in 1740 . Their purpose are to drain the low-lying water areas and protect the life of the early residents. Nineteen windmills are still working at present. In 1997, the Kinderdijk windmills were listed as UNESCO's World Heritage site, attracting many tourists every year, which is a typical example of the case of "landscape+engineering" in the Netherlands.

The Dutch concept of water management is also constantly updated, "room for water", to create more space for the river, and restore the ecosystem of riparian space. The Dutch experience also suggests a "layered design approach". This layer includes five levels of analysis and design: land type, housing policy, public space, urban pattern, and underground space. Professor Han Meyer of Delft University of Technology points out that the layered design method is to consider the climate of the surface layer and the dynamic state of the water area in the early stage of the design, and then carry out the design planning of the infrastructure, and then combine the economy, social and cultural elements of land use classification with the design, finally, it implements to the public space, architectural space planning and other details of the design [21].

Rotterdam Water Square Benthemplein is a good illustration of the typical case of design combined with water management. The water square is the first public space collected by rain water in the world. By combining landscape and engineering, water storage and public space are united. Water Square consists of three submersible squares, including sports grounds and leisure facilities. For most of the time, the square is a public space for leisure and entertainment in the city, and it will serve as a temporary reservoir for rain water only when it rains heavily. Starting water storage in the square is also a gradual process, gathering the rain water from a specific entrance and filtered into the centre of the square. Rainwater will not be saved too long in the square, It will flow into the city's open waterways in 30 hours [22]. Water Square Benthemplein combines landscape and engineering, and design with water management. This model provides a reference for the construction of sponge cities in China. (Figure 6, Figure 7)

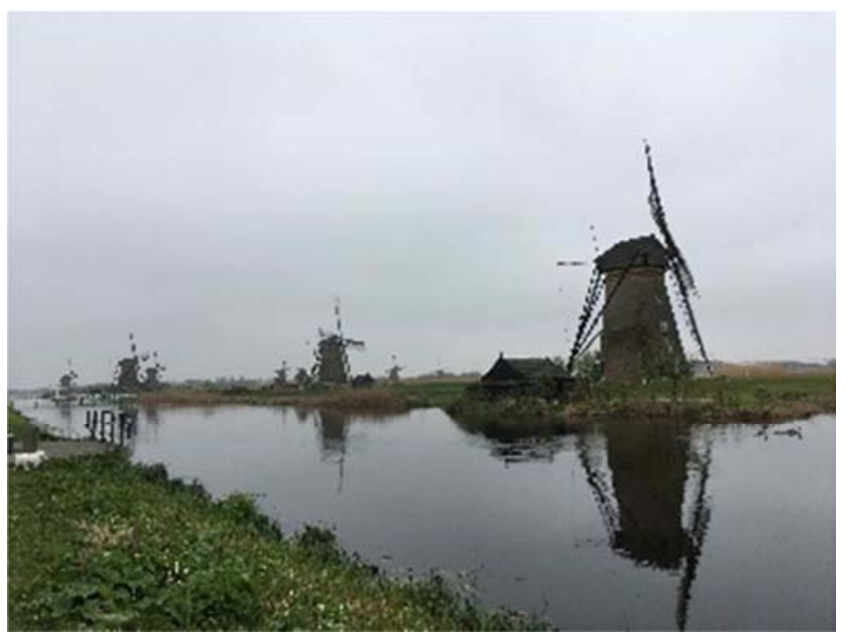

Figure 6. Kinderdijk

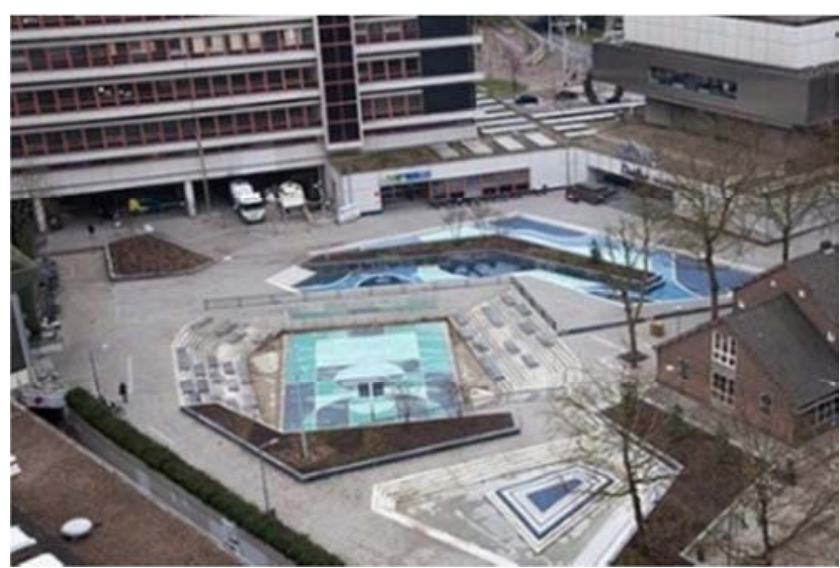

Figure 7. Benthemplein 
Source of Figure7:

http://jsj.zhenjiang.gov.cn/ztlm/jshmcs/tszs/201602/t20160202_1622612.htm

\section{Conclusion}

The era of global governance depends not only on technological and institutional innovation, but also on the revival, transformation and innovation of civilization. China's urbanization is moving towards a transitional period. How to develop the new urbanization, under the global background of resilient city, in the new period of Chinese urban construction environment guided by sponge city and ecological city, in order to restore and improve the adaptability and sustainability of urban development and strengthen the development of urban resilience, the paper holds that while the "industry-city" coordinated development is achieved in the delta metropolitan zone, it is a new trend of urban transformation and innovation to achieve cultural resilience and ecological resilience. Cultural resilience is the combing and reuse of historical urban context, while ecological resilience is a necessary condition to promote the adaptability and sustainability of urban development in the future.

\section{References}

[1] Wang, Yan; Wu, Wei; Boelens, Luuk. The interaction of city and water in Suzhou: Transformation, Urbanism, Resilience; in: 2018 International Conference on Smart Cities and Urban Design; 2018.

[2] "Yangtze (Yangzi, Changjiang) River Delta". China Today. Available online: http://www.chinatoday.com/city/china_yangtze_river_delta.ht m (accessed on 27 March 2013).

[3] Wang, Yan; Dong, Wei;Boelens, Luuk. The interaction of city and water in the Yangtze River Delta, A natural/artificial comparison with Euro Delta. Sustainability, 2018.

[4] LUUK BOELENS. Delta Governance: The DNA of a Specific Kind of Urbanization. BUILT ENVIRONMENT, 40(2), 169-183.

[5] Wang, Yan Wu, Wei. Boelens, Luuk. The construction and application of the theoretical framework in the interactive study of "water and city"; in: The 3rd International Conference on Research Paradigms Transformation in Social Sciences 2018; accepted, 2018.

[6] Schama, S.; Overvloed en Onbehagen. De Nederlandse Cultuur in de Gouden Eeuw; Contact: Amsterdam, The Netherlands, 1987; ISBN 9025466095.
[7] Tian Zichao, China Construction News, China - EU co-construction sustainable urbanization innovation platform, $11^{\text {th }}$, April, 2017.

[8] Yang Baojun: managing water and constructing city, China-up, $20^{\text {th }}$, November, 2017.

[9] City Cluster Plan for Yangtze River Delta, May, 2016.

[10] Urban system Planning in Southern Jiangsu Province (2012-2030), May, 2013.

[11] Demonstration Zone Plan for the Modernization of Southern Jiangsu Province, 2013.

[12] China Daily: Major infrastructure projects in China in past five years. August 22, 2017.

[13] Dong Wei: Grand Waterfront Cities in Transition- The case of the Yangtze River Delta, The Second International Seminar on the (historical) Interaction between Urban Development and Water management in Global Metropolitan Delta's, March 30, 2017.

[14] Tao Yanyu. Yangtze River Delta Urban agglomeration and Shanghai Metropolitan Circle from the Perspective of National High Speed Railway Strategy. Traffic \& Transportation, 2010 (5), 14-16.

[15] Wang Xingping: From the river network connection to the high-speed rail + Internet connection, The Second International Seminar on the (historical) Interaction between Urban Development and Water management in Global Metropolitan Delta's, March 30, 2017.

[16] P.Schmidt, Xu Junping. The European Union's Strategies for Small and Medium-sized Cities and Towns. Urban Planning International, 2013(5), 3-9.

[17] Jtirgen Rosemann, Hui Xiaoxi (translation). Urban transformations in the Netherlands. 2008, 22(1), 108-117.

[18] Li Di. Experience and Enlightenment of the development of urban agglomeration in northwest Europe. Globalization, 2015 (10), 41-52.

[19] Meng Fan-Lei, Liu Xin-Yi. Reviving the Port Heritage Site by Museums, Het Eilandje, Antwerp, Belgium. Urban Environment Design. 102(8), 2016.

[20] Yu Dan-Yang, Yang Zhen. Urban Design and Urban Renewal in England (1) when the Mist is gone: the Revival of the Waterfront Space of the Thames. Urban Planning International.

[21] Yu Yi, Chen Ruixin. Interpretation of the Delft University of Technology Prof. Han Meyer`s article: Why God can not prevent the Dutch living below sea level?

[22] Rain Water Square, Rotterdam, Netherlands. Architectural Journal. 